\title{
The Agr communication system provides a benefit to the populations of Listeria monocytogenes in soil
}

\author{
Anne-Laure Vivant ${ }^{1,2}$, Dominique Garmyn ${ }^{1,2}$, Laurent Gal ${ }^{2,3}$ and Pascal Piveteau ${ }^{1,2 *}$ \\ 1 Unités Mixtes de Recherche1347 Agroécologie, Université de Bourgogne, Dijon, France \\ 2 Institut National de la Recherche Agronomique, Unités Mixtes de Recherche1347 Agroécologie, Dijon, France \\ ${ }^{3}$ AgroSup Dijon, Unités Mixtes de Recherche1347 Agroécologie, Dijon, France
}

\section{Edited by:}

Martin John McGavin, University of Western Ontario, Canada

\section{Reviewed by:}

Robert J. C. McLean, TX State

University, USA

Hélène Marquis, Cornell University, USA

Lisa Gorski, Agricultural Research

Service, USA

\section{*Correspondence:}

Pascal Piveteau, Institut National de la Recherche Agronomique, Unités

Mixtes de Recherche1347

Agroécologie, 17 rue Sully, 21000

Dijon, France

e-mail: piveteau@u-bourgogne.fr
In this study, we investigated whether the Agr communication system of the pathogenic bacterium Listeria monocytogenes was involved in adaptation and competitiveness in soil. Alteration of the ability to communicate, either by deletion of the gene coding the response regulator AgrA (response-negative mutant) or the signal pro-peptide AgrD (signal-negative mutant), did not affect population dynamics in soil that had been sterilized but survival was altered in biotic soil suggesting that the Agr system of $L$. monocytogenes was involved to face the complex soil biotic environment. This was confirmed by a set of co-incubation experiments. The fitness of the response-negative mutant was lower either in the presence or absence of the parental strain but the fitness of the signal-negative mutant depended on the strain with which it was co-incubated. The survival of the signal-negative mutant was higher when co-cultured with the parental strain than when co-cultured with the response-negative mutant. These results showed that the ability to respond to Agr communication provided a benefit to listerial cells to compete. These results might also indicate that in soil, the Agr system controls private goods rather than public goods.

Keywords: Agr system, cell communication, competitiveness, fitness, Listeria monocytogenes, soil, biotic interaction

\section{INTRODUCTION}

For the last few decades, communication between bacteria has raised a growing interest. Cell-to-cell communication is based on the synthesis, the diffusion between cells and the perception of signal molecules. The perception of these molecules in the cell's extracellular environment induces the regulation of transcription and eventually adjustment of the physiology of the cell to its surrounding environmental conditions. Various communication systems have been described in the prokaryotic world. They differ according to the type of signal molecules and the machinery used to integrate the signal. To date, the communication systems most studied involve cyclic peptides (AIP), acyl-homoserine lactones (acyl-HSL) or auto-inducer-2 (AI-2) as signal molecules (Miller and Bassler, 2001; Reading and Sperandio, 2006; Atkinson and Williams, 2009).

Several social traits are regulated through cell-to-cell communication. Adhesion, biofilm formation and mobility require functional communication systems in several bacterial species (Labbate et al., 2004; Yarwood et al., 2004; Sturme et al., 2005; Rieu et al., 2007; Boles and Horswill, 2008; Fujii et al., 2008; Jayaraman and Wood, 2008; Riedel et al., 2009; Ray and Visick, 2012; Bowden et al., 2013). Public goods are exo-products as for example, virulence factors, surfactants or antibiotics produced and secreted by bacterial populations. Their production is usually under the control of the spatial distribution and density of cells and is dependent on the characteristics of mass transfer in the environment. For example, in Staphylococcus aureus (Morfeldt et al., 1995; Novick and Geisinger, 2008), Enterococcus faecalis (Qin et al., 2001; Nakayama et al., 2006), Clostridium perfringens (Vidal et al., 2011; Chen and McClane, 2012), Pseudomonas aeruginosa (Passador et al., 1993; Pearson et al., 1997), and Listeria monocytogenes (Autret et al., 2003; Riedel et al., 2009), communication systems control the secretion of the virulence factors required for the onset of infection. Moreover, survival mechanisms, such as sporulation, granulose formation, and antibiotic production are also controlled by communication systems in Clostridium acetobutylicum (Steiner et al., 2012), Pseudomonas chlororaphis (Morohoshi et al., 2013), and Bacillus subtilis (Comella and Grossman, 2005). These communicationdependent coordinated behaviors are examples of cooperation in the microbial world (Keller and Surette, 2006; Diggle et al., 2007). Such a social trait is vulnerable to exploitation by cheaters, these individuals that do not cooperate but gain the benefit from others cooperating (Velicer, 2003). Cheaters are individuals unable either to respond to the signal or to synthesize it. Cheaters have been isolated from populations of clinical and environmental P. aeruginosa (Salunkhe et al., 2005; Heurlier et al., 2006). Saving the cost of the production of the signal molecules, of their detection or production of exo-products (Diggle et al., 2007) may give cheaters an advantage and may decrease the value of cooperation (West et al., 2002; Rainey and Rainey, 2003). Experimentally, under controlled environments where access to public goods is required for growth, cheaters are fitter than individuals that cooperate (Rainey and Rainey, 2003; Diggle et al., 2007). Assessing the 
value of cooperation in natural settings is required in order to understand why communication and cooperation behaviors have been conserved so far in bacteria.

We tackled this issue with the bacterial model L. monocytogenes as this food-borne pathogen is ubiquitous in nature. It has been isolated from water systems (De Luca et al., 1998; Paillard et al., 2005; Lyautey et al., 2007), vegetation (Welshimer, 1968; Beuchat, 1996), farms (Nightingale et al., 2004; Fox et al., 2009; Latorre et al., 2010; Strawn et al., 2013), food industries (Goulet et al., 1998; Garrido et al., 2009; Serio et al., 2011), and feces of animals (Fenlon, 1985; Iida et al., 1991). It is also found in soil (Welshimer, 1960; Weis and Seeliger, 1975; Locatelli et al., 2013a; Vivant et al., 2013a). A communication system has been characterized in this organism. It is the Agr system that regulates adhesion, biofilm formation (Rieu et al., 2007; Riedel et al., 2009) and infection of mammalian hosts (Autret et al., 2003; Riedel et al., 2009). Four genes, agrBDCA, code the proteins required for Agr communication (Autret et al., 2003; Garmyn et al., 2009). Among them, agrD codes the propeptide AgrD processed into a mature autoinducing peptide (AIP) by AgrB; AgrA, the transcriptional regulator of the two component system AgrC/AgrA, is the response component of the system. Detection of AIP by the sensor AgrC triggers activation of AgrA. In order to investigate whether or not cooperation through communication provided an advantage to populations of L. monocytogenes in complex, natural environments, we compared the behavior of two communication mutants, a signal-negative mutant $\Delta a g r D$ unable to produce AIP but equipped to sense and respond to AIP, and a responsenegative mutant $\triangle a g r A$ unable to respond to extracellular signal, to the behavior of the parental strain following inoculation in soil.

\section{MATERIALS AND METHODS BACTERIAL STRAINS AND CULTURE MEDIA}

Rifampicin resistant strains were used in this study. The parental strain L. monocytogenes L9 is derived from L. monocytogenes EGDe (Lemunier et al., 2005). Rifampicin resistant isogenic mutants L. monocytogenes DG125A6 (this study) and L. monocytogenes DG119D9 (this study), respectively are $\triangle a g r A$ and $\triangle a g r D$ inframe deletion mutants (Rieu et al., 2007). Rifampicin resistant strains were isolated on Polymyxin-Acriflavin-Lithium-ChlorideCeftazidime-Aesculin-Mannitol agar (PALCAM; AES chemunex, Bruz, France) supplemented with $200 \mu \mathrm{g} \cdot \mathrm{ml}^{-1}$ rifampicine (Sigma-Aldrich, Saint Quentin Fallavier, France) according to Lemunier et al. (2005). For each strain, spontaneous Rif $^{\mathrm{R}}$ mutants were selected by comparing growth rates during planktonic growth and the ability to grow as biofilm in tryptone soy broth (TSB; AES chemunex, Bruz, France) at $25^{\circ} \mathrm{C}$ without shaking. L. monocytogenes DG125A6 was used as a response-negative mutant and L. monocytogenes DG119D9 as a signal-negative mutant.

A working stock stored at $-80^{\circ} \mathrm{C}$ was used throughout the study. Strains were grown statically at $25^{\circ} \mathrm{C}$ for $16 \mathrm{~h}$ in $5 \mathrm{ml}$ of TSB. Three independent inocula were prepared by inoculating $10 \mathrm{ml}$ of TSB $(1 \% \mathrm{v} / \mathrm{v})$ and incubating statically at $25^{\circ} \mathrm{C}$ to an O. $D_{600 \mathrm{~nm}}$ of 0.4 . The cultures were then centrifuged at $8000 \mathrm{~g}$ for $5 \mathrm{~min}$ at room temperature and pellets were suspended in
$\mathrm{NaCl}(0.85 \%)$. Cultures were adjusted to a concentration of $2.10^{8}$ $\mathrm{CFU} / \mathrm{ml}$.

\section{SOIL SAMPLES AND SOIL MICROCOSMS PREPARATION}

Soil was sampled in a pasture located in Burgundy, France. This sampling site belongs to a country-wide soil sampling network (RMQS) based on a $16 \times 16 \mathrm{~km}$ systematic grid covering the whole of France (Arrouays et al., 2002). Twenty-five individual core samples of topsoil $(0-30 \mathrm{~cm})$ were taken using a sampling design within an area of $20 \times 20 \mathrm{~m}$. The core samples were then mixed to obtain a composite sample. The soil sample was then sieved to $5 \mathrm{~mm}$ and stored at $4^{\circ} \mathrm{C}$. Aliquots of the soil were heat sterilized three times $\left(120^{\circ} \mathrm{C}, 20 \mathrm{~min}\right)$ with a period of $24 \mathrm{~h}$ between each autoclave treatment. Fifty g of sterilized and nonsterilized soil were packed in triplicate to constitute sterilized and biotic soil microcosms. Soil's attributes such as location, composition, chemistry, and land use are stored in the DONESOL database (Grolleau et al., 2004). Briefly, it is a clay soil with neutral $\mathrm{pH}$. Organic carbon and nitrogen content were respectively

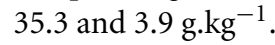

\section{SOIL MICROCOSM INOCULATION WITH SINGLE STRAIN AND CO-INOCULATION}

Single strain cultivation in biotic and sterilized soil were performed by inoculating a single strain, either L. monocytogenes L9, L. monocytogenes DG125A6 or L. monocytogenes DG119D9, at a concentration of $2.10^{6} \mathrm{CFU} / \mathrm{g}$ in $50 \mathrm{~g}$ soil microcosms. Microcosms were also co-inoculated with appropriate mixtures from individual cultures to a final ratio of 50:50 $\left(2.10^{6}: 2.10^{6} \mathrm{CFU} / \mathrm{g}\right)$. The following listerial mixtures were tested: L. monocytogenes L9/L. monocytogenes DG125A6, L. monocytogenes L9/L. monocytogenes DG119D9, and, L. monocytogenes DG125A6/L. monocytogenes DG119D9. Experiments were prepared in triplicates. All inoculated and co-inoculated microcosms were incubated at $25^{\circ} \mathrm{C}$ in the dark.

\section{ENUMERATION AND DETERMINATION OF LISTERIAL POPULATIONS DYNAMICS}

For single-cultures, listerial populations were enumerated by serial plating on Polymyxin-Acriflavin-Lithium-ChlorideCeftazidime-Aesculin-Mannitol agar (PALCAM; AES Chemunex, Bruz, France) supplemented with $100 \mu \mathrm{g} .1^{-1}$ cycloheximide and $100 \mu \mathrm{g} . \mathrm{l}^{-1}$ rifampicin (Sigma-Aldrich, Saint Quentin Fallavier, France) immediately after inoculation and periodically over a 14-days period for microcosms or over a 48 -h period for extracts.

In microcosms inoculated with 50/50 mixtures, the total number of listerial cells was enumerated as described above. The proportion of each of the two strains was determined by strainspecific PCR amplification (described below) from up to 96 colonies collected from the supplemented PALCAM plates.

\section{PCR AMPLIFICATION}

DNA template was prepared by transferring each colony in $200 \mu \mathrm{l}$ of water. Three sets of strain-specific primers were designed to discriminate co-inoculated strains. Two PCR reactions with two of the primer sets were required to discriminate co-inoculated strains. The sequences of the strain-specific primer sets and the 
genotype targeted are shown Table 1. PCR amplification was carried out in a final volume of $20 \mu \mathrm{l}$ containing $2.5 \mu \mathrm{l}$ of DNA template, $1 \mu \mathrm{l}$ of dimethyl sulfoxide (DMSO, Sigma-Aldrich, Saint Quentin Fallavier, France), $2 \mu$ l of 10X PCR buffer with $\mathrm{MgCl}_{2}, 0.16 \mu \mathrm{l}$ of dNTP mix $(25 \mathrm{mM}), 1.0 \mathrm{U}$ of Taq polymerase (MP Bio, Illkirch Graffenstaden, France), and a final concentration of $0.6 \mu \mathrm{M}$ of each primer. The following conditions were specifically determined and used: $95^{\circ} \mathrm{C}$ for $10 \mathrm{~min}, 30$ cycles of $15 \mathrm{sec}$ at $95^{\circ} \mathrm{C}, 50^{\circ} \mathrm{C}$ for $1 \mathrm{~min}$ and $72^{\circ} \mathrm{C}$ for $2 \mathrm{~min}$, followed by $7 \mathrm{~min}$ at $72^{\circ} \mathrm{C}$.

\section{COMPETITIVE INDEX DETERMINATION}

For each of the three replicates, the competitive Index (CI) was calculated as follows:

$$
\mathrm{CI}_{\mathrm{tx}}=\left(\left(\mathrm{CFU}_{\text {mutant }} / \mathrm{CFU}_{\text {parental }}\right)_{\mathrm{tx}} /\left(\mathrm{CFU}_{\text {mutant }} / \mathrm{CFU}_{\text {parental }}\right)_{\mathrm{t} 0}\right)
$$

Where $\mathrm{CI}_{\mathrm{tx}}$ is the competitive index at time $\mathrm{tx}(x=2$ days, 4 days, 7 days or 14 days), $\mathrm{CFU}_{\text {mutant }}$ and $\mathrm{CFU}_{\text {parental }}$ are the number of Colony Forming Units per gram of soil of the mutant and the parental strains, respectively, at time tx and at time t0. A CI score of 1 indicates no fitness difference. A similar calculation was realized for co-cultured listerial mutants.

\section{STATISTICAL ANALYSIS}

Patterns of survival of listerial populations were compared by repeated-measures analysis of variance (repeated-measures ANOVA) in both sterilized and biotic microcosms. To estimate whether or not the CI evolved over time, thus to determine whether a strain had a better ability to compete in soil, repeatedmeasures analysis of variance (repeated-measures ANOVA) was performed.

\section{RESULTS AND DISCUSSION DYNAMICS OF LISTERIAL POPULATIONS IN SOIL MICROCOSMS}

In sterilized soil microcosms, the population of the parental strain L. monocytogenes L9 increased of over $2 \log$ within the first 2 days of incubation and the population remained stable until the end of the experiment (Figure 1). Inactivation of the Agr system did not affect the dynamics of the mutants' population and no significant differences were observed between growth profiles of

Table 1 | Sequences of the strain-specific primer sets and genotypes targeted.

\begin{tabular}{llllc}
\hline $\begin{array}{l}\text { Primer } \\
\text { set }\end{array}$ & Oligonucleotide sequence $\mathbf{5}^{\prime} \boldsymbol{\rightarrow} \mathbf{3}^{\prime}$ & \multicolumn{2}{c}{$\begin{array}{l}\text { Genotype targeted } \\
\text { L. monocytogenes: }\end{array}$} \\
\cline { 3 - 5 } & & L9 & DG125A6 & DG119D9 \\
\hline C10 & CTTCAAACCCGGCATATCAT & + & + & + \\
C11 & GGAATGTTGGCGAATTTGTT & & & + \\
A19 & AATCCATGGTACCGGTTTTTATTTGT & + & - & + \\
A20 & CTCGAGTAAACTCAAGCTTTTAATA & & & + \\
B7 & AGCTAGCTGTCATGAAGTTTGTCTCG & + & + & - \\
D2 & AAGAATCCGCAACTTTCATGG & & & \\
\hline
\end{tabular}

+ amplification, - no amplification. the parental strain, the signal-negative $\Delta a g r D$ mutant and the response-negative $\triangle a g r A$ mutant. Similar results were collected during growth in sterilized soil extracts (data not shown). These results confirm previous reports on the ability of L. monocytogenes to multiply in sterilized soil (Dowe et al., 1997; Moshtaghi et al., 2009; McLaughlin et al., 2011; Piveteau et al., 2011). Moreover, our results suggest that the ability to produce AIP and to respond to the signal is not indispensable for growth of L. monocytogenes in this specific environment.

When indigenous microflora was not inactivated, in biotic soil microcosms, results were different (Figure 2). First of all, no growth was observed. The population of the parental strain was stable during the first 2 days of incubation thereafter the population declined throughout the duration of the experiment. Furthermore, the behavior of the mutants was significantly different. Indeed, the population of the two mutants declined sharply within the first 2 days of incubation and it was over 1 log lower than that of the parental strain from day 2 to the end of the experiment $(P<0.05)$. Differences between mutants were not significant. The results point out to the role of endogenous microbial communities in limiting implantation of L. monocytogenes in soil. Indeed, inactivation of telluric communities lifts inhibition (Dowe et al., 1997; Locatelli et al., 2013b; Vivant et al., 2013b). Moreover, microbial diversity is critical regarding the ability of soil microbial communities to limit invasion by L. monocytogenes (Vivant et al., 2013b). Our data strongly suggest that the activity of the Agr communication system is required for optimal survival of L. monocytogenes in soil. This suggests that the production of signal molecules and/or AgrA-mediated regulation improves the fitness of the populations of L. monocytogenes in soil. Moreover, production of private or public goods could be involved. In order to figure out if signal sensing in one hand or public goods production in the other hand underpinned the fitness advantage of the parental strain, we followed the fate of populations of the signalnegative and response-negative mutants during co-incubation with the parental strain in soil microcosms.

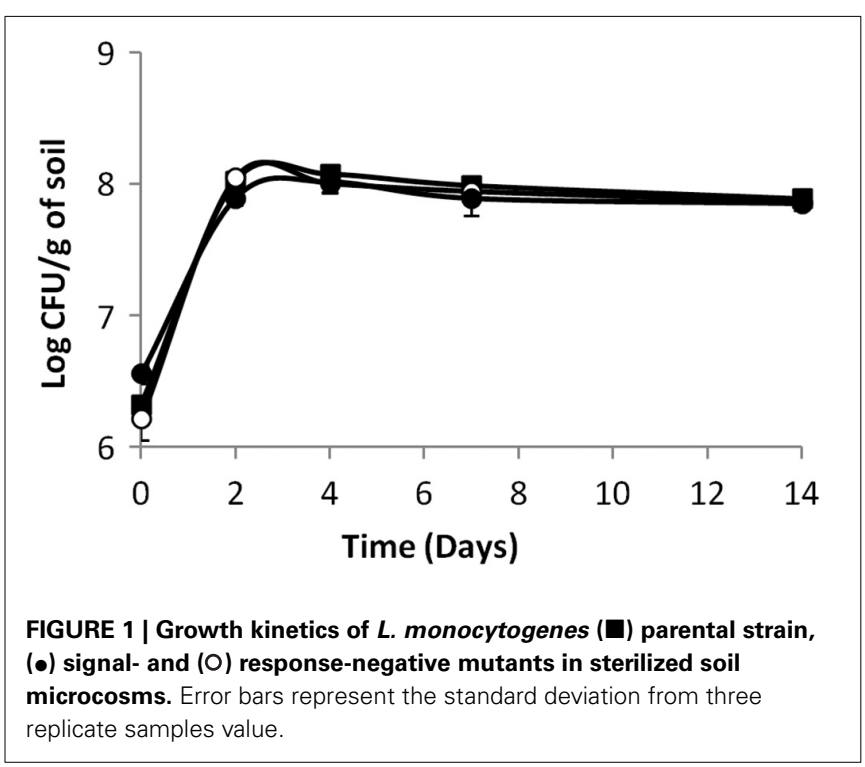




\section{COMPARISON OF THE FITNESS OF THE MUTANTS AND PARENTAL STRAINS IN SOIL MICROCOSMS}

To determine if alteration of the Agr communication system affected fitness in soil, we measured the survival of the parental strain and of both mutants in sterilized or biotic soil depending on whether they had been cultured with the parental strain, a mutant or as single listerial population. Moreover, Competitive Indexes (CI) of co-cultured listerial strains over a 14-days period in soil microcosms were calculated.

As shown in Figure 3, in sterilized soil microcosms, colonization profiles were similar for all strains whether they had been cultured as a single strain or with a partner. Moreover, variations of the CI were not significant (ANOVA, $P>0.05$ ) (Table 2). This is consistent with the results described above and confirms that in sterilized soil, in the absence of biotic pressure, inactivation of the Agr system does not alter the competitiveness of the mutants. Considering that in sterilized soil, cell density is higher than in biotic soil (about $4 \mathrm{log}$ ) and that scavenging of signal molecules is more limited, accumulation of signal molecules is expected.

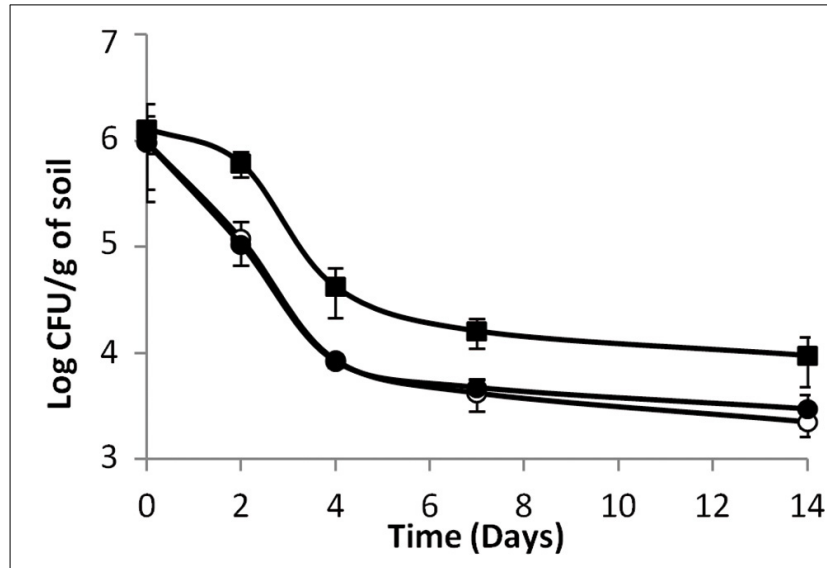

FIGURE 2 | L. monocytogenes ( $\square$ ) parental strain, (•) signal- and (O) response-negative mutants survival in biotic soil microcosms. Error bars represent the standard deviation from three replicate samples value.
This suggests that, under these experimental conditions, the AgrA-controlled features may not be essential for growth.

Under biotic conditions, survival of the parental strain (Figure 4A) and the response-negative mutant (Figure 4B) did not vary whatever the co-culture tested. On the opposite, results indicated a significant (ANOVA, $P<0.05$ ) improvement of the signal-negative mutant's survival when co-cultured with the parental strain but not when co-cultured with the responsenegative mutant (Figure 4C). This indicates that the fitness of the signal-mute strain depended of the presence or absence of cells with active Agr systems and that the parental strain provided a benefit to this mutant. In addition to this, CI measurements showed that under biotic conditions, the CI of the responsenegative mutant co-incubated with the parental strain significantly (ANOVA, $P<0.05$ ) decreased over time (Table 3 ). Under these conditions, the parental strain had a significant competitive advantage over the response-negative mutant. The inability to respond to Agr communication was detrimental to the survival of the response-negative mutant. This is supporting the idea that the Agr communication system is important for competitiveness of $L$. monocytogenes in soil when complex microbial communities are active. When the signal-negative mutant and the parental strain were co-inoculated, the analysis of variance

Table 2 | Competitive Indexes of co-cultured listerial strains over a 14-days period in sterilized soil microcosms.

\begin{tabular}{lccc}
\hline $\begin{array}{l}\text { Time } \\
\text { (Days) }\end{array}$ & $\begin{array}{c}\text { Response-negative } \\
\text { mutant/parental } \\
\text { strain }\end{array}$ & $\begin{array}{c}\text { Signal-negative } \\
\text { mutant/parental } \\
\text { strain }\end{array}$ & $\begin{array}{c}\text { Response-negative } \\
\text { mutant/signal- } \\
\text { negative mutant }\end{array}$ \\
\hline 0 & 1 & 1 & 1 \\
2 & 1.91 & 3.21 & 3.74 \\
4 & 1.50 & 1.37 & 1.03 \\
7 & 1.81 & 1.13 & 1.63 \\
14 & 1.67 & 1.68 & 1.12 \\
\hline
\end{tabular}

* Indicates when the $\mathrm{Cl}$ significantly differed from the time $\mathrm{O}$ (repeatedmeasures ANOVA, Tukey, $P<0.05$ ).

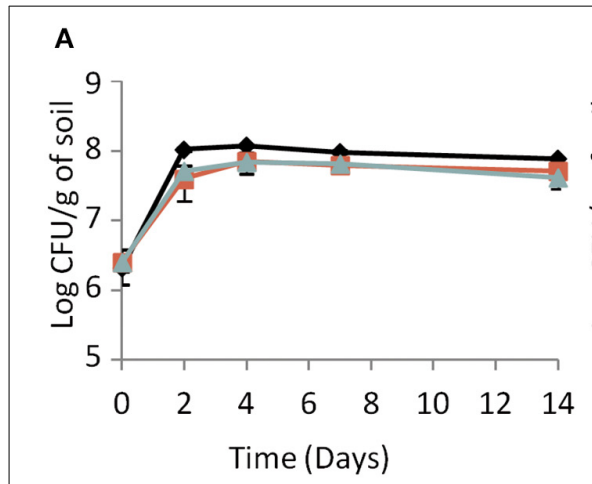

FIGURE 3 | Dynamics of (A) the parental strain, (B) the response-negative mutant and $(C)$ the signal-negative mutant populations in sterilized soil microcosms. (\$) Single culture, (O) co-culture
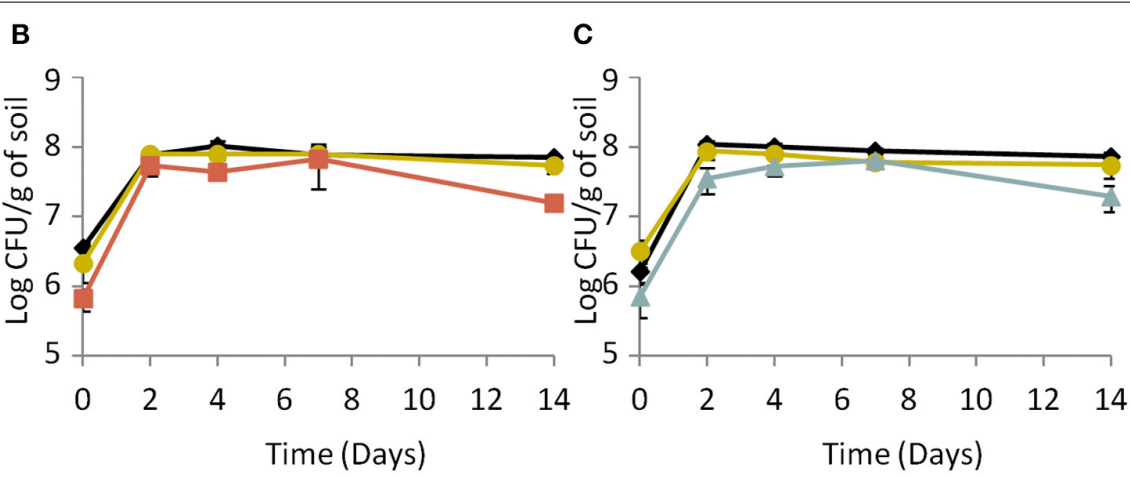

with the parental strain, $(\Delta)$ co-culture with the response-negative mutant, $(\square)$ co-culture with the signal-negative mutant. Error bars represent the standard deviation from three replicate samples value. 


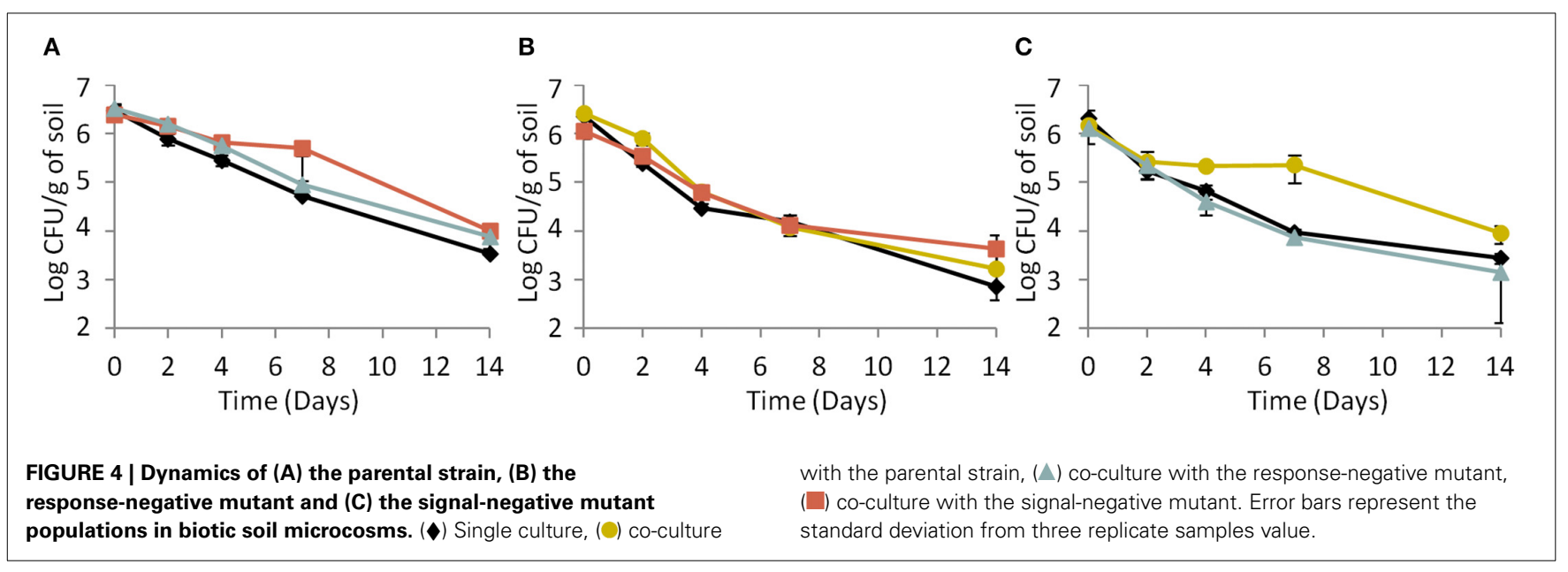

Table 3 | Competitive Indexes of co-cultured listerial strains over a 14-days period in biotic soil microcosms.

\begin{tabular}{lccc}
\hline $\begin{array}{l}\text { Time } \\
\text { (Days) }\end{array}$ & $\begin{array}{c}\text { Response-negative } \\
\text { mutant/parental } \\
\text { strain }\end{array}$ & $\begin{array}{c}\text { Signal-negative } \\
\text { mutant/parental } \\
\text { strain }\end{array}$ & $\begin{array}{c}\text { Response-negative } \\
\text { mutant/signal- } \\
\text { negative mutant }\end{array}$ \\
\hline 0 & 1 & 1 & 1 \\
2 & 0.54 & $0.31^{*}$ & 0.80 \\
4 & $0.20^{*}$ & 0.31 & 0.50 \\
7 & $0.25^{*}$ & 1.26 & 0.49 \\
14 & $0.26^{*}$ & 1.74 & 1.95 \\
\hline
\end{tabular}

* Indicates when the $\mathrm{Cl}$ significantly differed from the time 0 (repeatedmeasures ANOVA, Tukey, $P<0.05)$.

showed that the CI did not significantly vary over the 14 days of the experiment except after 2 days of incubation where the $\mathrm{CI}$ of the signal-negative mutant was significantly lower than the parental strain $(P<0.05)$ (Table 3$)$. These results suggest that, at later stages of incubation, the fitness of the signal-negative mutant was similar to the fitness of the parental strain during co-culture, confirming that the presence of the parental strain improved competitiveness of the signal-negative mutant. Finally, when the two mutants were tested in biotic soil microcosms, the CI did not vary significantly over time (Table 3 ) meaning that none of the mutants took advantage over the other during the 14 days of incubation.

These results show first of all that signal molecules accumulate to levels sufficient to promote induction of the Agr communication system. The minimal threshold required to induce communication and cell-density-dependent gene expression depends on properties of the environment such as water availability, masstransfer (Dulla and Lindow, 2008) and cell distribution (Hense et al., 2007). Under specific environmental conditions, with restricted diffusion of signal molecules, quorum can be reached even in small size populations. For example, on the surface of leaves, as few as 10 aggregated cells of Pseudomonas syringae can reach the quorum size (Dulla and Lindow, 2008). The local characteristics of soil such as the rates of diffusion and degradation of signal molecules and the cell density could generate a social environment propitious to communication between cells of $L$. monocytogenes even if present in small size populations.

Secondly, these results suggest that cells of the signal-mute population perceive and integrate signals produced by the parental strain into a concerted Agr response that restored the fitness of the signal-mute mutant. Such improvement was not observed with the response-negative mutant suggesting that under these experimental conditions, the Agr communication system regulates intracellular factors (private goods) rather than exo-products (public goods). Production of private goods promotes fitness advantage at the level of the individual cell in the bacterial models Pseudomonas aeruginosa and Bacillus subtilis (Dandekar et al., 2012; Darch et al., 2012; Oslizlo et al., 2014). Control of private goods by the Agr communication system is supported by results of transcriptomic analyses. Indeed, gene expression profile of the response-negative $\triangle a g r A$ mutant indicated that deletion of agrA resulted in deregulations of amino acids, purine, and pyrimidine synthesis pathways and nitrogen transport (Garmyn et al., 2012). In soil, adaptation of L. monocytogenes requires an extensive reprofiling of gene expression (Piveteau et al., 2011) and genes coding proteins involved in cellular processes (transport proteins) and intermediary metabolism (specific pathways for metabolism of carbohydrates) including chitinases and $\beta$-glucosidases are upregulated. In the telluric environment where nutrients can be scarce, bacteria must be able to use a large range of carbon and nitrogen sources, for example cellulose and by-products of its hydrolysis (vegetal residues) and chitin (arthropod exoskeleton and cell wall of fungi) polymers largely represented in nature, and to synthesize specific enzymes for their catabolism. The ability of L. monocytogenes to acquire and use these energy sources could be critical for its saprophytic life in soil.

Recently, chitin hydrolysis by L. monocytogenes was reported to be under the control of the Agr System (Paspaliari et al., 2014). In our experiment, although chitin hydrolysis could generate public goods, we did not evidence any detrimental effect of the presence of mutants to the fitness of the parental strain. Agr mutants did not seem to act as cheaters exploiting the benefit of cooperation under our experimental conditions. In soil, cellular density may be locally inappropriate to gain benefit of cooperation. Others 
have shown that induction of private goods can be dominant and mask the benefits of public goods (Dandekar et al., 2012). Considering social traits are vulnerable to cheaters, in populations of L. monocytogenes, Agr mutants should be isolated from environments where Agr communication mediates social traits. However, at the moment, no environmental or clinical isolates of $L$. monocytogenes has been reported with mutations in agrB$D C A$. On the opposite, $P$. aeruginosa cheaters have been isolated from specific, confined environments where diffusion of signal molecules is low and where the pathogen is able to settle for a long period (Sandoz et al., 2007). Characteristics of the various environments where most isolates of $L$. monocytogenes have been collected so far are not propitious to the emergence of cheaters.

\section{CONCLUSION}

The results reported here give new insights into the role of the Agr communication system in complex natural settings. First of all, the Agr communication system is required for optimal survival of L. monocytogenes in soil; secondly, it provides a benefit to L. monocytogenes populations in soil; thirdly, in the natural environment, production of signal molecules triggers a response in the receiving cells; and fourthly, the Agr system controls private goods. The question of whether the Agr system is a social trait of listerial populations remains to be investigated further. Indeed, the fact that the Agr system controls private goods does not exclude that it also controls public goods in specific habitats of $L$. monocytogenes.

\section{ACKNOWLEDGMENTS}

This work received a grant from the Regional Council of Burgundy (reference PARI AGRALE 11). The funders had no role in study design, data collection and analysis, decision to publish, or preparation of the manuscript.

\section{REFERENCES}

Arrouays, D., Jolivet, C., Boulonne, L., Bodineau, G., Saby, N., and Grolleau, E. (2002). A new initiative in France: a multi-institutional soil quality monitoring network. Fr. C. R. Acad. Agric. 88, 93-103.

Atkinson, S., and Williams, P. (2009). Quorum sensing and social networking in the microbial world. J. R. Soc. Interface 6, 959-978. doi: 10.1098/rsif. 2009.0203

Autret, N., Raynaud, C., Dubail, I., Berche, P., and Charbit, A. (2003). Identification of the agr locus of Listeria monocytogenes: role in bacterial virulence. Infect. Immun. 71, 4463-4471. doi: 10.1128/IAI.71.8.4463-4471.2003

Beuchat, L. R. (1996). Listeria monocytogenes: incidence on vegetables. Food Control 7, 223-228. doi: 10.1016/S0956-7135(96)00039-4

Boles, B. R., and Horswill, A. R. (2008). agr-mediated dispersal of Staphylococcus aureus biofilms. PLoS Pathog. 4:e1000052. doi: 10.1371/journal.ppat.1000052

Bowden, S. D., Hale, N., Chung, J. C. S., Hodgkinson, J. T., Spring, D. R., and Welch, M. (2013). Surface swarming motility by Pectobacterium atrosepticum is a latent phenotype that requires $\mathrm{O}$ antigen and is regulated by quorum sensing. Microbiology 159, 2375-2385. doi: 10.1099/mic.0.070748-0

Chen, J., and McClane, B. A. (2012). Role of the Agr-like quorum-sensing system in regulating toxin production by Clostridium perfringens type B strains CN1793 and CN1795. Infect. Immun. 80, 3008-3017. doi: 10.1128/IAI.00438-12

Comella, N., and Grossman, A. D. (2005). Conservation of genes and processes controlled by the quorum response in bacteria: characterization of genes controlled by the quorum-sensing transcription factor ComA in Bacillus subtilis. Mol. Microbiol. 57, 1159-1174. doi: 10.1111/j.1365-2958.2005.04749.x

Dandekar, A. A., Chugani, S., and Greenberg, E. P. (2012). Bacterial quorum sensing and metabolic incentives to cooperate. Science 338, 264-266. doi: $10.1126 /$ science. 1227289
Darch, S. E., West, S. A., Winzer, K., and Diggle, S. P. (2012). Density-dependent fitness benefits in quorum-sensing bacterial populations. Proc. Natl. Acad. Sci. U.S.A. 109, 8259-8263. doi: 10.1073/pnas.1118131109

De Luca, G., Zanetti, F., Fateh-Moghadm, P., and Stampi, S. (1998). Occurrence of Listeria monocytogenes in sewage sludge. Zentralbl. Hyg. Umweltmed. 201, 269-277.

Diggle, S. P., Griffin, A. S., Campbell, G. S., and West, S. A. (2007). Cooperation and conflict in quorum-sensing bacterial populations. Nature 450, 411-417. doi: 10.1038/nature06279

Dowe, M. J., Jackson, E. D., Mori, J. G., and Bell, C. R. (1997). Listeria monocytogenes survival in soil and incidence in agricultural soils. J. Food Prot. 60, 1201-1207.

Dulla, G., and Lindow, S. E. (2008). Quorum size of Pseudomonas syringae is small and dictated by water availability on the leaf surface. Proc. Natl. Acad. Sci. U.S.A. 105, 3082-3087. doi: 10.1073/pnas.0711723105

Fenlon, D. (1985). Wild birds and silage as reservoirs of Listeria in the agricultural environment. J. Bacteriol. 59, 537-543.

Fox, E., O’Mahony, T., Clancy, M., Dempsey, R., O’Brien, M., and Jordan, K. (2009). Listeria monocytogenes in the Irish dairy farm environment. J. Food Prot. 72, 1450-1456.

Fujii, T., Ingham, C., Nakayama, J., Beerthuyzen, M., Kunuki, R., Molenaar, D., et al. (2008). Two homologous Agr-like quorum-sensing systems cooperatively control adherence, cell morphology, and cell viability properties in Lactobacillus plantarum WCFS1. J. Bacteriol. 190, 7655-7665. doi: 10.1128/JB.01489-07

Garmyn, D., Augagneur, Y., Gal, L., Vivant, A.-L., and Piveteau, P. (2012). Listeria monocytogenes differential transcriptome analysis reveals temperaturedependent Agr regulation and suggests overlaps with other regulons. PLoS ONE 7:e43154. doi: 10.1371/journal.pone.0043154

Garmyn, D., Gal, L., Lemaitre, J.-P., Hartmann, A., and Piveteau, P. (2009). Communication and autoinduction in the species Listeria monocytogenes. Commun. Integr. Biol. 2, 371-374. doi: 10.4161/cib.2.4.8610

Garrido, V., Vitas, A. I., and Garcia-Jalon, I. (2009). Survey of Listeria monocytogenes in ready-to-eat products: prevalence by brands and retail establishments for exposure assessment of listeriosis in Northern Spain. Food Control 20, 986-991. doi: 10.1016/j.foodcont.2008.11.013

Goulet, V., Rocourt, J., Rebiere, I., Jacquet, C., Moyse, C., Dehaumont, P., et al. (1998). Listeriosis outbreak associated with the consumption of rillettes in France in 1993. J. Infect. Dis. 177, 155-160. doi: 10.1086/513814

Grolleau, E., Bargeot, L., Chafchafi, A., Hardy, R., Doux, J., Beaudou, A., et al. (2004). Le système d'information national sur les sols: DONESOL et les outils associés. Étude et Gestion des Sols 11, 255-269.

Hense, B. A., Kuttler, C., Mueller, J., Rothballer, M., Hartmann, A., and Kreft, J. U. (2007). Opinion - Does efficiency sensing unify diffusion and quorum sensing? Nat. Rev. Microbiol. 5, 230-239. doi:10.1038/nrmicrol600

Heurlier, K., Denervaud, V., and Haas, D. (2006). Impact of quorum sensing on fitness of Pseudomonas aeruginosa. Int. J. Med. Microbiol. 296, 93-102. doi: 10.1016/j.ijmm.2006.01.043

Iida, T., Kanzaki, M., Maruyama, T., Inoue, S., and Kaneuchi, C. (1991). Prevalence of Listeria monocytogenes in intestinal contents of healthy animals in Japan. J. Vet. Med. Sci. 53, 873-875. doi: 10.1292/jvms.53.873

Jayaraman, A., and Wood, T. K. (2008). Bacterial quorum sensing: signals, circuits, and implications for biofilms and disease. Annu. Rev. Biomed. Eng. 10, 145-167. doi: 10.1146/annurev.bioeng.10.061807.160536

Keller, L., and Surette, M. G. (2006). Communication in bacteria: an ecological and evolutionary perspective. Nature 4, 249-258. doi: 10.1038/nrmicro1383

Labbate, M., Queck, S. Y., Koh, K. S., Rice, S. A., Givskov, M., and Kjelleberg, S. (2004). Quorum sensing-controlled biofilm development in Serratia liquefaciens MG1. J. Bacteriol. 186, 692-698. doi: 10.1128/JB.186.3.692698.2004

Latorre, A. A., Kessel, J. S. V., Karns, J. S., Zurakowski, M. J., Pradhan, A. K., Boor, K. J., et al. (2010). Biofilm in milking equipment on a dairy farm as a potential source of bulk tank milk contamination with Listeria monocytogenes. J. Dairy Sci. 93, 2792-2802. doi: 10.3168/jds.2009-2717

Lemunier, M., Francou, C., Rousseaux, S., Houot, S., Dantigny, P., Piveteau, P., et al. (2005). Long-term survival of pathogenic and sanitation indicator bacteria in experimental biowaste composts. Appl. Environ. Microbiol. 71, 5779-5786. doi: 10.1128/AEM.71.10.5779-5786.2005

Locatelli, A., Depret, G., Jolivet, C., Henry, S., Dequiedt, S., Piveteau, P., et al. (2013a). Nation-wide study of the occurrence of Listeria monocytogenes in 
French soils using culture-based and molecular detection methods. J. Microbiol. Methods 93, 242-250. doi: 10.1016/j.mimet.2013.03.017

Locatelli, A., Spor, A., Jolivet, C., Piveteau, P., and Hartmann, A. (2013b). Biotic and abiotic soil properties influence survival of Listeria monocytogenes in soil. PLoS ONE 8:e75969. doi: 10.1371/journal.pone.0075969

Lyautey, E., Lapen, D. R., Wilkes, G., McCleary, K., Pagotto, F., Tyler, K., et al. (2007). Distribution and characteristics of Listeria monocytogenes isolates from surface waters of the South Nation River watershed, Ontario, Canada. Appl. Environ. Microbiol. 73, 5401-5410. doi: 10.1128/AEM.00354-07

McLaughlin, H. P., Casey, P. G., Cotter, J., Gahan, C. G. M., and Hill, C. (2011). Factors affecting survival of Listeria monocytogenes and Listeria innocua in soil samples. Arch. Microbiol. 193, 775-785. doi: 10.1007/s00203-011-0716-7

Miller, M. B., and Bassler, B. L. (2001). Quorum sensing in bacteria. Annu. Rev. Microbiol. 55, 165-199. doi: 10.1146/annurev.micro.55.1.165

Morfeldt, E., Taylor, D., Vongabain, A., and Arvidson, S. (1995). Activation of alpha-toxin translation in Staphylococcus aureus by the trans-encoded antisense RNA, RNAIII. EMBO J. 14, 4569-4577.

Morohoshi, T., Wang, W. Z., Suto, T., Saito, Y., Ito, S., Someya, N., et al. (2013). Phenazine antibiotic production and antifungal activity are regulated by multiple quorum-sensing systems in Pseudomonas chlororaphis subsp aurantiaca StFRB508. J. Biosci. Bioeng. 116, 580-584. doi: 10.1016/j.jbiosc.2013. 04.022

Moshtaghi, H., Garg, S. R., and Mandokhot, U. V. (2009). Survivability of Listeria monocytogenes in agricultural field soil. Indian J. Vet. Res. 18, 1-7.

Nakayama, J., Chen, S. M., Oyama, N., Nishiguchi, K., Azab, E. A., Tanaka, E., et al. (2006). Revised model for Enterococcus faecalis fsr quorum-sensing system: the small open reading frame $f s r D$ encodes the gelatinase biosynthesis-activating pheromone propeptide corresponding to staphylococcal AgrD. J. Bacteriol. 188, 8321-8326. doi: 10.1128/JB.00865-06

Nightingale, K. K., Schukken, Y. H., Nightingale, C. R., Fortes, E. D., Ho, A. J., Her, Z., et al. (2004). Ecology and transmission of Listeria monocytogenes infecting ruminants and in the farm environment. Appl. Environ. Microbiol. 70, 4458-4467. doi: 10.1128/AEM.70.8.4458-4467.2004

Novick, R. P., and Geisinger, E. (2008). Quorum sensing in Staphylococci. Annu. Rev. Genet. 42, 541-564. doi: 10.1146/annurev.genet.42.110807.091640

Oslizlo, A., Stefanic, P., Dogsa, I., and Mandic-Mulec, I. (2014). Private link between signal and response in Bacillus subtilis quorum sensing. Proc. Natl. Acad. Sci. U.S.A. 111, 1586-1591. doi: 10.1073/pnas.1316283111

Paillard, D., Dubois, V., Thiebaut, R., Nathier, F., Hoogland, E., Caumette, P., et al. (2005). Occurrence of Listeria spp. in effluents of French urban wastewater treatment plants. Appl. Environ. Microbiol. 71, 7562-7566. doi: 10.1128/AEM.71.11.7562-7566.2005

Paspaliari, D. K., Mollerup, M. S., Kallipolitis, B. H., Ingmer, H., and Larsen, M. H. (2014). Chitinase expression in Listeria monocytogenes is positively regulated by the Agr system. PLoS ONE 9:e95385. doi: 10.1371/journal.pone.0095385

Passador, L., Cook, J. M., Gambello, M. J., Rust, L., and Iglewski, B. H. (1993). Expression of Pseudomonas aeruginosa virulence genes requires cell-to-cell communication. Science 260, 1127-1130. doi: 10.1126/science.8493556

Pearson, J. P., Pesci, E. C., and Iglewski, B. H. (1997). Roles of Pseudomonas aeruginosa las and $r h l$ quorum-sensing systems in control of elastase and rhamnolipid biosynthesis genes. J. Bacteriol. 179, 5756-5767.

Piveteau, P., Depret, G., Pivato, B., Garmyn, D., and Hartmann, A. (2011). Changes in gene expression during adaptation of Listeria monocytogenes to the soil environment. PLoS ONE 6:e24881. doi: 10.1371/journal.pone.0024881

Qin, X., Singh, K. V., Weinstock, G. M., and Murray, B. E. (2001). Characterization of Fsr, a regulator controlling expression of gelatinase and serine protease in Enterococcus faecalis OG1RF. J. Bacteriol. 183, 3372-3382. doi: 10.1128/JB.183.11.3372-3382.2001

Rainey, P. B., and Rainey, K. (2003). Evolution of cooperation and conflict in experimental bacterial populations. Nature 425, 72-74. doi: 10.1038/nature01906

Ray, V. A., and Visick, K. L. (2012). LuxU connects quorum sensing to biofilm formation in Vibrio fischeri. Mol. Microbiol. 86, 954-970. doi: 10.1111/mmi.12035

Reading, N. C., and Sperandio, V. (2006). Quorum sensing: the many languages of bacteria. FEMS Microbiol. Lett. 254, 1-11. doi: 10.1111/j.15746968.2005.00001.x

Riedel, C. U., Monk, I. R., Casey, P. G., Waidmann, M. S., Gahan, C. G. M., and Hill, C. (2009). AgrD-dependent quorum sensing affects biofilm formation, invasion, virulence and global gene expression profiles in Listeria monocytogenes. Mol. Microbiol. 71, 1177-1189. doi: 10.1111/j.1365-2958.2008.06589.x
Rieu, A., Weidmann, S., Garmyn, D., Piveteau, P., and Guzzo, J. (2007). agr system of Listeria monocytogenes EGD-e: role in adherence and differential expression pattern. Appl. Environ. Microbiol. 73, 6125-6133. doi: 10.1128/AEM.00608-07

Salunkhe, P., Smart, C. H. M., Morgan, J. A. W., Panagea, S., Walshaw, M. J., Hart, C. A., et al. (2005). A cystic fibrosis epidemic strain of Pseudomonas aeruginosa displays enhanced virulence and antimicrobial resistance. J. Bacteriol. 187, 4908-4920. doi: 10.1128/JB.187.14.4908-4920.2005

Sandoz, K. M., Mitzimberg, S. M., and Schuster, M. (2007). Social cheating in Pseudomonas aeruginosa quorum sensing. Proc. Natl. Acad. Sci. U.S.A. 104, 15876-15881. doi: 10.1073/pnas.0705653104

Serio, A., Chaves-Lopez, C., and Paparella, A. (2011). Listeria monocytogenes isolated from the smoked salmon industry: growth potential under different environmental conditions. Food Control 22, 2071-2075. doi: 10.1016/j.foodcont.2011.05.010

Steiner, E., Scott, J., Minton, N. P., and Winzer, K. (2012). An agr quorum sensing system that regulates granulose formation and sporulation in Clostridium acetobutylicum. Appl. Environ. Microbiol. 78, 1113-1122. doi: 10.1128/AEM. 06376-11

Strawn, L. K., Fortes, E. D., Bihn, E. A., Nightingale, K. K., Gröhn, Y. T., Worobo, R. W., et al. (2013). Landscape and meteorological factors affecting prevalence of three food-borne pathogens in fruit and vegetable farms. Appl. Environ. Microbiol. 79, 588-600. doi: 10.1128/AEM.02491-12

Sturme, M. H. J., Nakayama, J., Molenaar, D., Murakami, Y., Kunugi, R., Fujii, T., et al. (2005). An agr-like two-component regulatory system in Lactobacillus plantarum is involved in production of a novel cyclic peptide and regulation of adherence. J. Bacteriol. 187, 5224-5235. doi: 10.1128/JB.187.15.5224-5235.2005

Velicer, G. J. (2003). Social strife in the microbial world. Trends Microbiol. 11, 330-337. doi: 10.1016/S0966-842X(03)00152-5

Vidal, J. E., Ma, M., Saputo, J., Garcia, J., Uzal, F. A., and McClane, B. A. (2011). Evidence that the Agr-like quorum sensing system regulates the toxin production, cytotoxicity and pathogenicity of Clostridium perfringens type C isolate CN3685. Mol. Microbiol. 83, 1287-1287. doi: 10.1111/j.1365-2958.2012.07997.x

Vivant, A. L., Garmyn, D., Maron, P. A., Nowak, V., and Piveteau, P. (2013b). Microbial diversity and structure are drivers of the biological barrier effect against Listeria monocytogenes in soil. PLoS ONE 8:e76991. doi: 10.1371/journal.pone.0076991

Vivant, A.-L., Garmyn, D., and Piveteau, P. (2013a). Listeria monocytogenes, a pathogen down-to-earth. Front. Cell. Infect. Microbiol. 3:87. doi: $10.3389 /$ fcimb. 2013.00087

Weis, J., and Seeliger, H. P. R. (1975). Incidence of Listeria monocytogenes in nature. Appl. Microbiol. 30, 29-32.

Welshimer, H. J. (1960). Survival of Listeria monocytogenes in soil. J. Bacteriol. 80, 316-320.

Welshimer, H. J. (1968). Isolation of Listeria monocytogenes from vegetation. J. Bacteriol. 95, 300-303.

West, S. A., Pen, I., and Griffin, A. S. (2002). Conflict and cooperation Cooperation and competition between relatives. Science 296, 72-75. doi: 10.1126/science. 1065507

Yarwood, J. M., Bartels, D. J., Volper, E. M., and Greenberg, E. P. (2004). Quorum sensing in Staphylococcus aureus biofilms. J. Bacteriol. 186, 1838-1850. doi: 10.1128/JB.186.6.1838-1850.2004

Conflict of Interest Statement: The authors declare that the research was conducted in the absence of any commercial or financial relationships that could be construed as a potential conflict of interest.

Received: 26 August 2014; paper pending published: 24 September 2014; accepted: 17 October 2014; published online: 06 November 2014.

Citation: Vivant A-L, Garmyn D, Gal L and Piveteau P (2014) The Agr communication system provides a benefit to the populations of Listeria monocytogenes in soil. Front. Cell. Infect. Microbiol. 4:160. doi: 10.3389/fcimb.2014.00160

This article was submitted to the journal Frontiers in Cellular and Infection Microbiology.

Copyright $\odot 2014$ Vivant, Garmyn, Gal and Piveteau. This is an open-access article distributed under the terms of the Creative Commons Attribution License (CC BY). The use, distribution or reproduction in other forums is permitted, provided the original author(s) or licensor are credited and that the original publication in this journal is cited, in accordance with accepted academic practice. No use, distribution or reproduction is permitted which does not comply with these terms. 